\title{
Odpowiedzialność karna za przestępstwa z art. 55a ust. 1-2 oraz kontratyp z art. 55a ust. 3 ustawy o Instytucie Pamięci Narodowej - Komisji Ścigania Zbrodni przeciwko Narodowi Polskiemu ${ }^{1}$
}

\begin{abstract}
Criminal Liability referred to in article 55a paragraphs 1-2 and its exclusion ("kontratyp") article 55a paragraphs 3 of the Act on the Institute of National Remembrance Commission for the Prosecution of Crimes against the Polish Nation: The provisions of the Act, which are the subject of questions presented in the order to prepare the expert opinion, ceased to be in force on the $17^{\text {th }}$ July 2018. A fundamental legal effect of the of the legislator's decision to repeal them is decriminalization of behaviors covered by the statutory description of the type of prohibited act. The most important conclusion of the expert opinion is even in the period of time the provisions of article 55a paragraphs $1-2$ were in force representatives of German minority in Poland had the possibility of conducting activities in favor of "discovering, elaborating and commemorating the tragic fate of the German civilian population, embedded in the system of post-war labor camps" under condition they did not contradict the facts.
\end{abstract}

Keywords: Institute of National Remembrance, crime, national minorities

Słowa kluczowe: Instytut Pamięci Narodowej, przestępczość, mniejszości narodowe

Ekspert ds. legislacji BAS; pawel.bachmat@sejm.gov.pl.

\section{Przedmiot opinii}

Przedmiotem opinii jest analiza wybranych aspektów uregulowania art. 55a ust. 1-3 ustawy z 18 grudnia 1998 r. o Instytucie Pamięci Narodowej - Komisji Ścigania Zbrodni przeciwko Narodowi Polskiemu (t.j. Dz.U. 2016, poz. 1575, ze zm.; dalej: ustawa o IPN). Przepis art. 55a ust. 1-3 zostały wprowadzone ustawą z 26 stycznia 2018 r. o zmianie ustawy o Instytucie Pamięci Narodowej - Komisji Ścigania Zbrodni przeciwko Narodowi Polskiemu, ustawy o grobach i cmenta-

1 Opinia prawna na temat typów czynów zabronionych oraz kontratypu określonych $w$ art. 55a ust. 1-3 ustawy o Instytucie Pamięci Narodowej - Komisji Ścigania Zbrodni sporządzona 26 lipca 2018 r. na zlecenie posła; BAS-WAP 794/18. 
rzach wojennych, ustawy o muzeach oraz ustawy o odpowiedzialności podmiotów zbiorowych za czyny zabronione pod groźbą kary (Dz.U. 2018, poz. 369). Weszły w życie z dniem 1 marca 2018 r. w następującym ujęciu redakcyjnym: 1. Kto publicznie i wbrew faktom przypisuje Narodowi Polskiemu lub Państwu Polskiemu odpowiedzialność lub współodpowiedzialność za popetnione przez III Rzeszę Niemieckg zbrodnie nazistowskie określone w art. 6 Karty Międzynarodowego Trybunału Wojskowego załaczonej do Porozumienia międzynarodowego w przedmiocie ścigania i karania głównych przestępców wojennych Osi Europejskiej, podpisanego w Londynie dnia 8 sierpnia 1945 r. (Dz. U. z 1947 r. poz. 367), lub za inne przestępstwa stanowiące zbrodnie przeciwko pokojowi, ludzkości lub zbrodnie wojenne lub w inny sposób rażąco pomniejsza odpowiedzialność rzeczywistych sprawców tych zbrodni, podlega grzywnie lub karze pozbawienia wolności do lat 3. Wyrok jest podawany do publicznej wiadomości.

2. Jeżeli sprawca czynu określonego w ust. 1 działa nieumyślnie, podlega grzywnie lub karze ograniczenia wolności.

3. Nie popetnia przestępstwa sprawca czynu zabronionego określonego w ust. 1 i 2, jeżeli dopuścił się tego czynu w ramach działalności artystycznej lub naukowej.

W związku z cytowanym wyżej brzmieniem art. 55a ust. 1-3 ustawy o IPN wyrażono obawę, co do możliwości pogodzenia działań przedstawicieli niemieckiej mniejszości w Polsce prowadzonych na rzecz: odkrywania, opracowywania i upamiętniania tragicznych losów cywilnej ludności niemieckiej, osadzonej w systemie powojennych obozów pracy z zakresem kryminalizacji wyznaczonym na podstawie powołanych przepisów ustawy o IPN. W szczególności zaś zwrócono uwagę na zachodzącą obawę pociągnięcia do odpowiedzialności karnej osób zaangażowanych w tego typu działalność, jak również świadków wydarzeń tamtych lat publicznie prezentujących swoje wspomnienia. Wątpliwości te zostały ujęte w następujące pytaniach:

„1) Czy art. 55a ustawy może w sposób obiektywny utrudnić bądź też zahamować proces odkrywania systemu zbrodni powojennych na terenie Polski oraz oddawania czci niemieckim ofiarom tychże zbrodni, w przestrzeni publicznej lub w mediach?

2) Historia wielu powojennych obozów pracy, prowadzonych również przez administrację polską, nie została jeszcze odkryta i odpowiednio zbadana. W związku z tym rodzi się pytanie, czy art. 55a ustawy może narażać na odpowiedzialność karną osoby, które w działaniach publicznych i medialnych będą zajmowały się opracowywaniem tej trudnej i nieodkrytej jeszcze historii lub będą o niej opowiadać, wysuwając przy tym różne tezy o odpowiedzialności konkretnych osób, podmiotów, czy też państwa polskiego (w zależności od źródeł, z których korzystają). W opinii środowiska [które reprezentuje poseł zgłaszający wątpliwości] art. 55a może być wykorzystywany jako narzędzie do walki z osobami, które na forum publicznym lub medialnym będą przypisywać odpowiedzialność państwu polskiemu za przestępstwa stanowiące zbrodnie przeciw- 
ko pokojowi, ludzkości lub zbrodnie wojenne w okresie powojennym w oparciu o wyniki swoich badań lub posługując się już dostępnymi opracowaniami lub badaniami, które w danym momencie będą prowadzone przez historyków i naukowców. Również świadkowie tamtych zbrodni, którzy opowiedzą o nich na forum publiczno-medialnym na podstawie swojej wiedzy i pamięci z wydarzeń tamtych lat, mogą być narażeni na odpowiedzialność karną. Czy obawy te w związku z art. 55a są uzasadnione?

3) W jaki sposób organy powołane do ścigania przestępstwa $z$ art. 55a ust. 3 będą rozgraniczać działalność artystyczną lub naukową danego naukowca/historyka od jego wypowiedzi w mediach? W jaki sposób będzie dokonywana ocena, czy dana wypowiedź miała charakter naukowy, czy publicystyczny?”.

Należy zastrzec, że zgodnie z art. 1 pkt 2 ustawy z 27 czerwca 2018 r. o zmianie ustawy o Instytucie Pamięci Narodowej - Komisji Ścigania Zbrodni przeciwko Narodowi Polskiemu oraz ustawy o odpowiedzialności podmiotów zbiorowych za czyny zabronione pod groźbą kary (Dz.U. 2018, poz. 1272) uregulowanie art. 55a ustawy o IPN, będące punktem odniesienia dla sformułowanych wyżej pytań, ulega uchyleniu po upływie 14 dniu od ogłoszenia ustawy nowelizującej, które nastąpiło 2 lipca 2018 r. Przepisy art. 55a ust. 1-3 przestały zatem obowiązywać z dniem 17 lipca 2018 r.

Przedstawiona opinia uwzględnia stan prawny na dzień jej sporządzenia, została przygotowana na podstawie następujących aktów normatywnych:

- ustawy z 18 grudnia 1998 r. o Instytucie Pamięci Narodowej - Komisji Ścigania Zbrodni przeciwko Narodowi Polskiemu,

- ustawy z 26 stycznia 2018 r. o zmianie ustawy o Instytucie Pamięci Narodowej - Komisji Ścigania Zbrodni przeciwko Narodowi Polskiemu, ustawy o grobach i cmentarzach wojennych, ustawy o muzeach oraz ustawy o odpowiedzialności podmiotów zbiorowych za czyny zabronione pod groźbą kary i wszedł w życie; dalej: nowelizacja ustawy o IPN z 26 stycznia 2018 r.,

- ustawy z 27 czerwca 2018 r. o zmianie ustawy o Instytucie Pamięci Narodowej - Komisji Ścigania Zbrodni przeciwko Narodowi Polskiemu oraz ustawy o odpowiedzialności podmiotów zbiorowych za czyny zabronione pod groźbą kary; dalej: nowelizacja ustawy o IPN z 27 czerwca 2018 r.,

- konwencji w sprawie zapobiegania i karania zbrodni ludobójstwa uchwalonej przez Zgromadzenie Ogólne Narodów Zjednoczonych 9 grudnia 1948 r., Dz.U. 1952, nr 2, poz. 9; dalej: konwencja ONZ z 1948 r.,

- ustawy z 6 czerwca 1997 r. - Kodeks karny, t.j. Dz.U. 2017, poz. 2204, ze zm.; dalej: Kodeks karny lub k.k.,

- ustawy z 6 czerwca 1997 r. - Kodeks postępowania karnego, t.j. Dz.U. 2017, poz. 1904, ze zm.; dalej: k.p.k.,

- ustawy z 6 czerwca 1997 r. - Kodeks karny wykonawczy, t.j. Dz.U. 2018, poz. 652 , ze zm.; dalej: k.k.w. 


\section{Uzasadnienie prawne}

\section{Zmiana stanu prawnego w zakresie opiniowanych przepisów ustawy o IPN}

Jak wskazano wyżej, przepisy art. 55a ust. 1-3 ustawy o IPN weszły w życie z dniem 1 marca 2018 r., ale na skutek nowelizacji ustawy o IPN z 27 czerwca 2018 r. zostały uchylone i przestały obowiązywać z dniem 17 lipca 2018 r. Odnotowana zmiana normatywna doprowadziła do zaistnienia szczególnej sytuacji intertemporalnej przy kwalifikowaniu czynów określonych w uchylanych przepisach art. 55a ust. 1 i 2 ustawy o IPN, jak również zachowań realizowanych w granicach kontratypu $z$ art. 53 ust. 3 ustawy o IPN.

Zasadniczym skutkiem prawnym decyzji ustawodawcy o uchyleniu art. 55a ust. 1 i 2 ustawy o IPN jest dekryminalizacja zachowań objętych ustawowym opisem typu czynu zabronionego określonego $\mathrm{w}$ tych przepisach $\mathrm{w}$ jego umyślnej i nieumyślnej odmianie. Z praktycznego punktu widzenia oznacza to zatem, że od dnia 17 lipca 2018 r. czyn sprawcy realizujący znamiona opisane w uchylanych przepisach art. 55a ust. 1 albo art. 55a ust. 2 ustawy o IPN pozostaje na gruncie prawa karnego zachowaniem legalnym i nie podlega ściganiu.

Istotne jest tu jednak uczynienie zastrzeżenia, że wprowadzana zmiana w prawnej ocenie zdarzeń, których modelowy odpowiednik zapisany został w dyspozycjach uchylanych przepisów, ogranicza się do zakresu normowania prawa karnego. Nowelizacja ustawy o IPN z 27 czerwca 2018 r. nie uchyliła bowiem szczególnej, cywilnoprawnej podstawy ochrony dobrego imienia Rzeczypospolitej Polskiej i narodu polskiego, jaka przewidziana została w rozdziale 6c ustawy o IPN, w tym zwłaszcza w art. 53o ustawy o IPN, który stanowi, że: [d]o ochrony dobrego imienia Rzeczypospolitej Polskiej i Narodu Polskiego odpowiednie zastosowanie maja przepisy ustawy $z$ dnia 23 kwietnia 1964 r. - Kodeks cywilny (Dz. U. z 2017 r. poz. 459, 933 i 1132) o ochronie dóbr osobistych. Powództwo o ochronę dobrego imienia Rzeczypospolitej Polskiej lub Narodu Polskiego może wytoczyć organizacja pozarządowa w zakresie swoich zadań statutowych. Odszkodowanie lub zadośćuczynienie przystuguja Skarbowi Państwa.

Nie budzi przy tym wątpliwości, że w zakresie przesłanki „naruszenia dobrego imienia Rzeczypospolitej Polskiej lub Narodu Polskiego" mieszczą się różnorakie zachowania polegające na kłamliwym (wbrew faktom) przypisywaniu narodowi polskiemu lub państwu polskiemu odpowiedzialności lub współodpowiedzialności za popełnienie zbrodni, w tym zbrodni rodzajowo wskazanych w uchylanym art. 55a ust. 1 ustawy o IPN. Tak więc należy mieć na uwadze, że nawet po 17 lipca 2018 r. osoba dopuszczająca się kłamliwego (wbrew faktom) przypisania narodowi polskiemu lub państwu polskiemu odpowiedzialności lub współodpowiedzialności za popełnienie zbrodni rodzajowo wskazanych w uchylanym art. 55a ust. 1 ustawy o IPN, których dopuścił się kto inny, powinna liczyć się z możliwością poniesienia odpowiedzialności przed polskimi sądami z tytułu naruszenia 
dobrego imienia Rzeczypospolitej Polskiej lub narodu polskiego. Wspomniana odpowiedzialność zaktualizuje się w reżimie prawa cywilnego i może prowadzić do zasądzenia obowiązku wypłaty odszkodowania lub zadośćuczynienia na rzecz Skarbu Państwa. Tytułem uzupełnienia warto dodać, że, zgodnie z art. 53p ustawy o IPN, powództwo o ochronę dobrego imienia Rzeczypospolitej Polskiej lub narodu polskiego wytoczyć może również Instytut Pamięci Narodowej (w sprawach tych Instytut Pamięci Narodowej ma bowiem przyznaną zdolność sądową), a stosownie do art. 53q ustawy o IPN przepisy art. 53o i art. 53p ustawy o IPN znajdą zastosowanie niezależnie od tego, jakie prawo jest właściwe.

Wracając do kwestii dekryminalizacji zachowań objętych dyspozycją przepisów art. 55a ust. 1 i 2 ustawy o IPN, należy dodać, że logiczną konsekwencją uchylenia $\mathrm{z}$ dniem 17 lipca 2018 r. przepisów art. 55a ust. 1 i 2 ustawy o IPN było także uchylenie z tym samym dniem jej art. 55a ust. 3, przewidującego kontratyp (tj. okoliczność wyłączającą przestępność czynu z uwagi na brak jego bezprawności) legalizujący popełnienie czynów $\mathrm{z}$ art. 55a ust. 1 i 2 ustawy o IPN w ramach działalności artystycznej lub naukowej. Skoro zachowania stypizowane w uchylanych art. 55a ust. 1 i 2 ustawy o IPN nie będą stanowiły już przestępstwa, a więc będą na gruncie prawa karnego pierwotnie legalne, nie ma potrzeby utrzymywania podstawy prawnej dla ich wtórnej legalizacji w drodze wyłączenia ich bezprawnego charakteru na gruncie prowadzonej działalności artystycznej lub naukowej.

Skutek dekryminalizacyjny w odniesieniu do przestępstw z art. 55a ust. 1 i 2 ustawy o IPN, który zaktualizował się z dniem 17 lipca 2018 r., wpłynie przede wszystkim na ocenę zachowań przyszłych. Przepisy art. 55a ust. 1 i 2 ustawy o IPN obowiązywały jednak od 1 marca 2018 r. Tym samym w okresie wyznaczonym powołanymi datami, tj. od 1 marca do 17 lipca 2018 r., prawnokarna ocena zachowań stypizowanych $\mathrm{w}$ art. 55a ust. 1 i 2 ustawy o IPN była diametralnie odmienna. Podlegały one ściganiu i ukaraniu jako czyny zabronione ustawą karną. Nie można przy tym wykluczyć, że w zarysowanym okresie (tj. przed dekryminalizacją) jakieś osoby dopuściły się zachowań wypełniających znamiona typów czynów zabronionych określonych w przepisach art. 55a ust. 1 i 2 ustawy o IPN, a nawet że stały się one przedmiotem wszczętych postępowań karnych. W związku z tym należy rozważyć pytanie, czy ich sprawcy nadal powinni liczyć się z groźbą poniesienia odpowiedzialności karnej.

Ogólnej wskazówki do odpowiedzi na to pytanie udzielił ustawodawca, który w części ogólnej Kodeksu karnego zawarł normę zawierającą dyrektywę intertemporalną rozstrzygającą podobne sytuacje. Zgodnie z art. $4 \$ 1$ k.k., jeżeli w czasie orzekania obowiązuje ustawa inna niż w czasie popełnienia przestępstwa, stosuje się ustawę nową, jednakże należy stosować ustawę obowiązującą poprzednio, jeżeli jest względniejsza dla sprawcy. W analizowanym przypadku nie budzi wątpliwości, iż względniejsza dla sprawcy jest ustawa nowa (tj. nowelizacja ustawy o IPN z 27 czerwca 2018 r.), gdyż poddaje modelowy odpowiednik jego zachowania dekryminalizacji. Tak więc to ona znajdzie zastosowanie 
do oceny czynów mających miejsce w okresie od 1 marca do 17 lipca 2018 r., a będących przedmiotem postępowań, w których orzekanie nastąpi począwszy od dnia 17 lipca 2018 r. Z perspektywy oceny dokonywanej ex post zachowanie sprawcy zostanie zatem objęte skutkiem dekryminalizacyjnym.

Powyższe ustalenie materialnoprawne przełoży się od strony procesowej w zależności od stanu zaawansowania prowadzonego postępowania - na etapie postępowania przygotowawczego: na odmowę jego wszczęcia albo umorzenie postępowania już prowadzonego $z$ art. $17 \$ 1$ pkt 2 k.p.k. (czyn nie zawiera znamion czynu zabronionego), a na etapie postępowania sądowego - uniewinnienie (art. $414 \$ 1$ k.p.k. w związku z art. $17 \$ 1$ pkt 2 k.p.k.) $)^{2}$.

W celu zobrazowania w pełni sytuacji intertemporalnej na gruncie Kodeksu karnego należy jeszcze wspomnieć o przypadku osoby, wobec której organy wymiaru sprawiedliwości zdążyłyby przeprowadzić w całości postępowanie karne o przestępstwo $\mathrm{z}$ art. 55a ust. 1 albo ust. 2 ustawy o IPN, zakończone prawomocnym skazaniem przed dniem 17 lipca 2018 r. Otóż, zgodnie z dyrektywą zawartą w art. $4 \$ 4$ k.k., jeżeli według nowej ustawy czyn objęty wyrokiem nie jest już zabroniony pod groźbą kary, to skazanie ulega zatarciu z mocy prawa. Jeśli natomiast w momencie wejścia w życie nowej ustawy toczyłoby się postępowanie wykonawcze dotyczące takiego wyroku (wykonywana byłaby orzeczona kara pozbawienia wolności, kara ograniczenia wolności, ewentualnie trwałby okres próby w związku z warunkowym umorzeniem postępowania albo warunkowym zawieszeniem wykonania orzeczonej kary pozbawienia wolności), przedmiotowe postępowanie należałoby umorzyć z powołaniem się na art. $15 \$ 1$ k.k.w.

\section{Odniesienie się ex post do pytań}

\section{- Ad 1) i 2)}

W uchylonym art. 55a ust. 1 ustawy o IPN ustawodawca dokonał typizacji umyślnego typu czynu zabronionego polegającego na: publicznym i wbrew fak-

2 Należy nadmienić, że termin „orzekanie” rozumiany jest na gruncie art. $4 \$ 1$ k.k. szerzej niż np. „wyrokowanie”. Jak wskazuje L. Lachowski, „orzekanie” obejmuje zarówno wydanie wyroku w I instancji, jak i II instancji, a także na etapie orzekania kasacyjnego oraz na skutek wznowienia postępowania. Przez pojęcie orzekania należy rozumieć także wydawanie wyroku łącznego po zmianie ustawy (por. wyroki SN z: 9 stycznia 2015 r., sygn. akt IV KK 224/14, LEX nr 1622330; 7 listopada 2014 r., sygn. akt II KK 284/14, LEX nr 1539462; 17 lipca 2014 r., sygn. akt V KK 211/14, „Prokuratura i Prawo”, wkładka, 2014, nr 10, poz. 1, oraz 25 czerwca 2014 r., sygn. akt II KK 139/14, „Prokuratura i Prawo”, wkładka, 2014, nr 10, poz. 2). Orzekaniem będzie również wydawanie postanowienia o umorzeniu postępowania przygotowawczego, postanowienia o przedstawieniu zarzutów, postanowienia o stosowaniu środków zabezpieczających. Szerzej zob. J. Lachowski, Komentarz do art. 4 [w:] Kodeks karny. Komentarz, red. V. Konarska-Wrzosek, 2016, LEX nr 513055. 
tom przypisywaniu Narodowi Polskiemu lub Państwu Polskiemu odpowiedzialności lub współodpowiedzialności za popetnione przez III Rzeszę Niemiecka zbrodnie nazistowskie określone w art. 6 Karty Międzynarodowego Trybunatu Wojskowego załączonej do Porozumienia międzynarodowego w przedmiocie ścigania i karania głównych przestępców wojennych Osi Europejskiej, podpisanego w Londynie dnia 8 sierpnia 1945 r. (Dz. U. z 1947 r. poz. 367), lub za inne przestępstwa stanowiace zbrodnie przeciwko pokojowi, ludzkości lub zbrodnie wojenne lub w inny sposób rażącym pomniejszaniu odpowiedzialności rzeczywistych sprawców tych zbrodni.

Na podstawie art. 55a ust. 2 ustawy o IPN penalizacji poddana została także nieumyślna odmiana tego typu czynu zabronionego.

Odnosząc ustawowy opis typu czynu zabronionego $\mathrm{z}$ art. 55a ust. 1 i 2 ustawy o IPN, w jego odmianie umyślnej i nieumyślnej, do dwóch pierwszych pytań będących przedmiotem opinii, należy na wstępie zaznaczyć, iż zakres kryminalizacji wyznaczony na tej podstawie wykracza w znacznej części poza stany faktyczne wskazane w treści pytań. Jak można wywnioskować, historycznym punktem odniesienia dla sformułowanych wątpliwości jest okres przypadający po II wojnie światowej i działalność władz sowieckich oraz instalowanych przy ich pomocy polskojęzycznych ośrodków władzy, podejmowana w powojennym okresie wobec cywilnej ludności niemieckiej. Przy tak określonej granicy temporalnej należy uznać, że poza zakresem analizy pozostaje ten fragment norm dekodowanych na podstawie dawnych przepisów art. 55a ust. 1 i 2 ustawy o IPN, który obejmuje, dokonywane publicznie i wbrew faktom:

- przypisywanie narodowi polskiemu lub państwu polskiemu odpowiedzialności lub współodpowiedzialności za zachowania podjęte w trakcie trwania II wojny światowej, a więc zbrodnie popełnione w warunkach wojennych, w tym:

- popełnione przez III Rzeszę Niemiecką zbrodnie nazistowskie określone w art. 6 Karty Międzynarodowego Trybunału Wojskowego załączonej do Porozumienia międzynarodowego $\mathrm{w}$ przedmiocie ścigania i karania głównych przestępców wojennych Osi Europejskiej, podpisanego w Londynie 8 sierpnia 1945 r. (Dz.U. 1947, poz. 367),

- inne przestępstwa stanowiące zbrodnie przeciwko pokojowi,

- inne zbrodnie wojenne,

- lub dokonane w inny sposób rażące pomniejszanie odpowiedzialności rzeczywistych sprawców tych zbrodni.

Przy tym założeniu relewantny dla dalszej analizy pozostaje jedynie ten fragment norm dekodowanych na podstawie uchylonych przepisów art. 55a ust. 1 i 2 ustawy o IPN, który obejmuje:

- zakaz dokonywania publicznie i wbrew faktom przypisywania narodowi polskiemu lub państwu polskiemu odpowiedzialności lub współodpowiedzialności za inne przestępstwa stanowiące „zbrodnie przeciwko ludzkości”, 
- lub zakaz dokonywania w inny sposób - publicznie i wbrew faktom - rażącego pomniejszania odpowiedzialności rzeczywistych sprawców tych zbrodni.

Pojęcie „zbrodni przeciwko ludzkości” ma na gruncie typów czynu zabronionego $\mathrm{z}$ art. 55a ust. 1 i 2 ustawy o IPN charakter znamienia odsyłającego. W art. 3 ustawy o IPN zamieszczona została jego ustawowa definicja, według której: [z]brodniami przeciwko ludzkości sa w szczególności zbrodnie ludobójstwa $w$ rozumieniu Konwencji w sprawie zapobiegania i karania zbrodni ludobójstwa, przyjętej w dniu 9 grudnia 1948 r. (Dz. U. z 1952 r. poz. 9, 10 i 213 oraz z 1998 r. poz. 177), a także inne poważne prześladowania $z$ powodu przynależności osób prześladowanych do określonej grupy narodowościowej, politycznej, społecznej, rasowej lub religijnej, jeżeli były dokonywane przez funkcjonariuszy publicznych albo przez nich inspirowane lub tolerowane. Z kolei, zgodnie $\mathrm{z}$ zawartym $\mathrm{w}$ tym przepisie dalszym odesłaniem do konwencji ONZ z 1948 r., pod pojęciem „zbrodni ludobójstwa" rozumie się na gruncie art. II tego traktatu którykolwiek z wymienionych niżej czynów, dokonany w zamiarze zniszczenia w całości lub części grup narodowych, etnicznych, rasowych lub religijnych, jako takich:

- zabójstwo członków grupy,

- spowodowanie poważnego uszkodzenia ciała lub rozstroju zdrowia psychicznego członków grupy,

- rozmyślne stworzenie dla członków grupy warunków życia, obliczonych na spowodowanie ich całkowitego lub częściowego zniszczenia fizycznego,

- stosowanie środków, które mają na celu wstrzymanie urodzin w obrębie grupy,

- przymusowe przekazywanie dzieci członków grupy do innej grupy.

W tym miejscu należy jednak przypomnieć, że zgodnie ze stylizacją przyjętą w uchylonym art. 55a ust. 1 ustawy o IPN dla przypisania odpowiedzialności karnej za zachowanie realizujące znamiona typu czynu zabronionego określonego w art. 55a ust. 1 albo 2 ustawy o IPN konieczne było, aby sprawca sformułował swój przekaz „wbrew faktom”. Słowo fakt w ujęciu słownikowym oznacza zdarzenie, zjawisko, sytuację lub stan rzeczy, które rzeczywiście miały miejsce (zaszły w rzeczywistości) ${ }^{3}$. Sprawca czynu z art. 55a ust. 1 i 2 ustawy o IPN miał więc formułować przekaz obiektywnie nieprawdziwy (fałszywy), przypisując narodowi polskiemu lub państwu polskiemu m.in. odpowiedzialność za zbrodnie przeciwko ludzkości, za które ani naród, ani państwo polskie odpowiedzialne nie są. Dodać należy, że obiektywnie możliwa do ustalenia fałszywość twierdzeń sprawcy takiego czynu może wynikać albo z faktu, iż podnoszone przez niego wydarzenia nie miały w ogóle miejsca albo, wprawdzie miały miejsce, ale odpowiedzialność za ich wydarzenie się ponosi rodzajowo inny podmiot.

3 Inny słownik języka polskiego PWN. A...Ó, red. M. Bańko, Warszawa 2000, s. 393; Uniwersalny słownik języka polskiego, t. I, $A-G$, red. S. Dubisz, Warszawa 2003, s. 872. 
Wprowadzenie do ustawowego opisu typu czynu zabronionego znamienia uzależniającego odpowiedzialność sprawcy od nieprawdziwości przedstawionego przez niego przekazu wiązało się z ważną funkcją limitującą zakres kryminalizacji wyznaczonej na podstawie uchylonych uregulowań. Zabieg ten racjonalizował również dopuszczenie przez ustawodawcę skutku w postaci ograniczenia swobody wypowiedzi, z jakim należało się liczyć w czasie obowiązywania art. 55a ust. 1 i 2 ustawy o IPN. Karalne pozostawało zatem przypisywanie narodowi polskiemu lub państwu polskiemu jedynie obiektywnie niezgodnej z prawdą odpowiedzialności lub współodpowiedzialności za popełnienie wymienionych w treści art. 55a ust. 1 ustawy o IPN rodzajów zbrodni, w tym zbrodni przeciwko ludzkości. Z czysto logicznego punktu widzenia, wnioskując a contrario, kryminalizacją na podstawie uchylonych art. 55a ust. 1 i 2 ustawy o IPN nie były więc nigdy objęte przypadki, w których ktoś przypisywałby narodowi polskiemu lub państwu polskiemu odpowiedzialność lub współodpowiedzialność za określone $\mathrm{w}$ tych przepisach rodzaje zbrodni, pod warunkiem że czynił to, odwołując się do historycznie potwierdzonych zdarzeń, a więc działał w zgodzie z faktami.

To ostatnie twierdzenie wymaga jednak pewnego zniuansowania tak, aby jego ogólne brzmienie nie prowadziło do wyciągania fałszywych wniosków na gruncie pojęć narodu i państwa polskiego. W opisie trudnych czasów powojennych należy rekomendować zachowanie daleko posuniętej ostrożności w doborze słów identyfikujących podmioty odpowiedzialne za popełnienie określonych zbrodni, czego praktyczna egzemplifikacja mogłaby być dokonana jedynie na tle indywidualnych okoliczności sprawy. Jednak rozważając tę kwestię w oderwaniu od konkretnego stanu faktycznego, w ujęciu czysto hipotetycznym, należy zwrócić uwagę, iż nawet potwierdzenie faktycznego sprawstwa określonych osób czy grup nie może żadną miarą przełożyć się na konkluzję generalizującą, prowadzącą do przypisania odpowiedzialności za zbrodnie tych konkretnych osób całej zbiorowości narodowej, z której się wywodzą. Nie może to mieć miejsca przynajmniej do zaistnienia pewnego progu masowości zdarzeń, który jednak pozostaje trudny do granicznego uchwycenia, będąc w swojej istocie kryterium dalece uznaniowym. Tak więc nieostrożna generalizacja może prowadzić do formułowania twierdzeń nieuprawnionych, skutkujących odpowiedzialnością autora takich słów, który przed dniem 17 lipca 2018 r., zakładając, że nie podpadał pod dyspozycję uchylonego art. 55a ust. 3 ustawy o IPN, powinien był liczyć się nawet z groźbą pociągnięcia do odpowiedzialności karnej z art. 55a ust. 1 albo 2 ustawy o IPN. Z kolei w obowiązującym stanie prawnym osoba taka wciąż powinna liczyć się z możliwością poniesienia odpowiedzialności w trybie art. 53o ustawy o IPN z tytułu naruszenia dobrego imienia Rzeczypospolitej Polskiej lub narodu polskiego.

Podobną ostrożność należałoby zachować w związku z próbą przypisania odpowiedzialności państwu polskiemu np. za zbrodnie przeciwko ludzkości towarzyszące przetrzymywaniu cywilnej ludności niemieckiej w obozach pracy po II wojnie światowej. Powiązanie tych zdarzeń wedle kryterium geograficznego z ak- 
tualnym terytorium państwa polskiego nie powinno przesłaniać faktu, że substrat państwowości, jakim jest władza, pozostawał wówczas pod całkowitą kontrolą sowiecką. Przypisaniu odpowiedzialności za popełnienie określonych zbrodni konkretnemu państwu powinno z kolei towarzyszyć ustalenie, że kwestionowane na gruncie tej odpowiedzialności zdarzenia historyczne stanowią efekt autonomicznego procesu decyzyjnego organów państwa, które staje pod zarzutem. Trudno mówić o odpowiedzialności państwa polskiego za określone decyzje w sytuacji obecności na jego terytorium wojsk sowieckich oraz sowieckich dublerów w strukturze tworzonej administracji, jak również w sytuacji, w której nowo powstające, polskojęzyczne organy władzy tworzone były wbrew woli większości jego mieszkańców w oderwaniu, a nawet z jawnym pogwałceniem legitymacji demokratycznej oraz przy ignorowaniu istnienia polskich organów władzy na uchodźstwie i w podziemiu. Ten obraz zbliża sytuację, w której znalazła się polska państwowość, raczej do stanu państwa okupowanego, ofiary obcego imperializmu, aniżeli sprawcy bezprawia pociąganego do odpowiedzialności dziejowej.

Nie kwestionując faktu, że na terytorium państwa polskiego, w okresie powojennym, a także w czasie poprzedzającym zakończenie II wojny światowej, ludność cywilna, niezależnie zresztą od jej pochodzenia narodowego, stała się przedmiotem licznych represji ze strony tworzonego tam polskojęzycznego aparatu władzy czy struktur wojskowo-policyjnych ZSRR, należy podnieść, że sposób opisywania tych zdarzeń z perspektywy identyfikacji podmiotów odpowiedzialnych za wyrządzone bezprawie wymaga ponadstandardowej skrupulatności i z pewnością unikania posługiwania się upraszczającymi uogólnieniami. Należy przyznać, iż poszukiwanie adekwatnego aparatu pojęciowego nie jest na tym tle zadaniem łatwym, ale z pewnością nie niemożliwym. Nota bene pewna wskazówka terminologiczna została zawarta już w treści ustawy z 18 grudnia 1998 r. o Instytucie Pamięci Narodowej - Komisji Ścigania Zbrodni przeciwko Narodowi Polskiemu, która w przepisie art. 2 posługuje się kategoriami „zbrodni komunistycznych” oraz „funkcjonariuszy państwa komunistycznego”. Warto dodać, że przywołany tu sposób dookreślenia kręgu rzeczywistych sprawców zarzucanych zbrodni, zakładający powiązanie ich z wyznawaną ideologią, nie jest autorskim rozwiązaniem polskiego ustawodawcy. Już wcześniej został on wykorzystany np. w niemieckim dyskursie historyczno-publicystycznym, gdzie odpowiedzialność za okropieństwa II wojny światowej dość konsekwentnie wiązana bywa ostatnimi laty z działalnością „nazistów”, nie zaś Niemców, którzy, mimo niedowierzania połączonego ze sprzeciwem polskiej opinii publicznej, coraz częściej zyskują przy tej okazji status chronologicznie pierwszej ofiary nazistów.

Powracając do wątpliwości wyrażonych we wstępie niniejszej opinii, co do narażenia na odpowiedzialność karną - w okresie obowiązywania art. 55a ust. 1 i 2 ustawy o IPN - osób zajmujących się opracowywaniem historii powojennych obozów pracy działających na ziemiach polskich, warto zwrócić uwagę jeszcze na dwie kwestie. 
Po pierwsze, w okresie obowiązywania tych przepisów ustawodawca dopuszczał w wąskim zakresie możliwość legalnego wypełnienia znamion typów czynów zabronionych określonych $\mathrm{w}$ art. 55a ust. 1 i 2 ustawy o IPN na mocy kontratypu określonego w jej art. 55a ust. 3, zgodnie z którym nie popełniał przestępstwa ten, kto dopuszczał się tych czynów w ramach działalności artystycznej lub naukowej. Powyższa kwalifikacja prawnomaterialna przekładała się od strony procesowej - w zależności od stanu zaawansowania prowadzonego postępowania - na etapie postępowania przygotowawczego: na odmowę jego wszczęcia albo umorzenie postępowania już prowadzonego $\mathrm{z}$ art. $17 \S 1$ pkt 2 k.p.k. (ustawa stanowi, że sprawca nie popełnia przestępstwa), zaś na etapie postępowania sądowego - uniewinnienie (art. $414 \$ 1$ k.p.k. w związku z art. $17 \$ 1$ pkt 2 k.p.k.).

Powołany wyżej kontratyp nie obejmował natomiast innych rodzajów działalności publicznej w tym np. publicystycznej, dziennikarskiej czy politycznej. Oznaczało to, że osoba, która w swojej wypowiedzi publicznej, podkreślmy to wbrew faktom - przypisywała narodowi polskiemu lub państwu polskiemu odpowiedzialność lub współodpowiedzialność za zbrodnie wymienione $\mathrm{w}$ treści dyspozycji art. 55a ust. 1 ustawy o IPN lub w inny sposób rażąco pomniejszała odpowiedzialność rzeczywistych sprawców tych zbrodni, a nie dokonywała tego w ramach działalności artystycznej lub naukowej, tylko np. w ramach działalności czysto publicystycznej, albo bez powiązania z jakąkolwiek działalnością zawodową, prezentując to jako swój osobisty punkt widzenia, musiała liczyć się z pociągnięciem do odpowiedzialności karnej.

Po drugie, należy nadmienić, że prawdopodobieństwo popadnięcia w kolizję $\mathrm{z}$ prawnokarnym zakazem było wówczas stosunkowo łatwe $\mathrm{z}$ uwagi na przyjęte założenie kryminalizacyjne ścigania sprawców tak umyślnego, jak i nieumyślnego popełnienia typu czynu zabronionego $\mathrm{z}$ art. 55a ustawy o IPN. Odwołując się do zgeneralizowanych w art. 9 k.k. postaci strony podmiotowej czynu zabronionego, w grę wchodził zarówno zamiar bezpośredni, jak i zamiar ewentualny oraz nieumyślne odmiany strony podmiotowej: nieumyślność świadoma i nieumyślność nieświadoma.

Co to oznaczało w praktyce? Zagrożony karą był nie tylko sprawca działający ze złej woli, a więc ten, kto, mając świadomość obiektywnej nieprawdziwości głoszonych tez, przypisywał publicznie narodowi polskiemu lub państwu polskiemu odpowiedzialność lub współodpowiedzialność za zbrodnie wymienione w treści dyspozycji art. 55a ust. 1 ustawy o IPN lub w inny sposób rażąco pomniejszał odpowiedzialność rzeczywistych sprawców tych zbrodni, chcąc przy tym dopuścić się popełnienia czynu zabronionego $\mathrm{z}$ art. 55a ust. 1 ustawy o IPN (zamiar bezpośredni), albo przewidując taką możliwość na to się godził (zamiar ewentualny). Ściganiu podlegała także osoba działająca nieumyślnie, która nie miała wprawdzie zamiaru popełnienia czynu zabronionego, ale nie dochowała też wymaganych $\mathrm{w}$ tych okolicznościach standardów ostrożności, zakładających konieczność uprzedniego potwierdzenia głoszonych publicznie 
tez wedle kryterium ich fałszywości bądź prawdziwości i niegłoszenie tez nieprawdziwych, pozostających w kolizji z faktami. Na tej zasadzie odpowiedzialności karnej podlegał sprawca nieumyślnego popełnienia czynu zabronionego, którego stosunek psychiczny do czynu zabronionego, w tym do będącego jego składową nieprawdziwego (wbrew faktom) „przypisywania odpowiedzialności lub współodpowiedzialności” albo „rażącego umniejszania odpowiedzialności rzeczywistych sprawców”, mógł przybrać jedną z dwóch postaci. Sprawca taki mógł, po pierwsze, przewidywać możliwość popełnienia czynu zabronionego, tj. obejmować swoją świadomością wątpliwość, że głoszone przez niego tezy mogą kolidować z faktami, a mimo to bezpodstawnie przypuszczać, że nie doprowadzi to do postawienia mu zarzutu karnego (nieumyślność świadoma). W drugim scenariuszu sprawca przestępstwa $\mathrm{z}$ art. 55a ust. 2 ustawy o IPN nie uświadamiał sobie nawet, że wygłoszone pod adresem narodu lub państwa polskiego zarzuty są nieprawdziwe, choć w danych okolicznościach mógł to przewidzieć (nieumyślność nieświadoma).

To w ówczesnym ściganiu zachowań popełnionych w nieuświadomionej nieumyślności leżało niebezpieczeństwo łatwego popadnięcia w kolizję z art. 55a ust. 2 ustawy o IPN osób działających $\mathrm{z}$ ignorancji. Ale nawet w tym przypadku, zakładającym, że sprawca typu czynu zabronionego z art. 55a ust 2 ustawy o IPN dopuścił się swojego zachowania nieświadomie, w stanie osobistej niewiedzy, punktem odniesienia dla jego odpowiedzialności były fakty już historycznie potwierdzone. Innymi słowy, nie byłoby możliwe skuteczne przypisanie odpowiedzialności karnej z art. 55a ust. 2 ustawy o IPN osobie, która, działając w warunkach braku historycznych ustaleń, próbowała w dobrej wierze dokonać samodzielnego ich odkrycia, co istotne, działając poza sferą naukową (działalność naukowa była bowiem już objęta kontratypem z ówczesnego art. 55a ust. 3 ustawy o IPN), na pewnym etapie doszła do pewnych ustaleń, które upubliczniła, a które następnie zostały zakwestionowane, gdyż chronologicznie późniejsze badania im zaprzeczyły. Należy przyjąć, że taka osoba nie popełniała przestępstwa ze względu na to, iż jej zachowanie miało znamiona działania w usprawiedliwionym błędzie, co do okoliczności stanowiącej znamię czynu zabronionego, w tym wypadku w błędzie co do znamienia „wbrew faktom”, co skutkowało, zgodnie $\mathrm{z}$ art. $28 \$ 1$ k.k., wyłączeniem jej zawinienia, a przez to przestępności popełnionego przez nią czynu ${ }^{4}$.

4 Możliwość odniesienia błędu co do faktu do czynów popełnionych nieumyślnie zaistniała z dniem 1 lipca 2015 r. na skutek wejścia w życie nowelizacji art. $28 \$ 1$ k.k., dokonanej art. 1 pkt 4 ustawy z 20 lutego 2015 r. o zmianie ustawy - Kodeks karny oraz niektórych innych ustaw, Dz.U. poz. 396. Szerzej na ten temat zob. m.in.: P. Kozłowska-Kalisz, Komentarz aktualizowany do art. 28 [w:] M. Budyn-Kulik, P. Kozłowska-Kalisz, M. Kulik, M. Mozgawa, Kodeks karny. Komentarz aktualizowany, 2018, LEX nr 560561; J. Lachowski, Komentarz do art. 28 [w:] Kodeks karny. Komentarz, red. V. Konarska-Wrzosek, 2016,LEX nr 513081. 


\section{- Ad 3)}

Jak wskazano już we wcześniejszej części niniejszej opinii, uchylony przepis art. 55a ust. 3 ustawy o IPN regulował instytucję kontratypu, wyłączającego przestępność czynów określonych w uchylonym art. 55a ust. 1 i 2 ustawy o IPN, a popełnionych $\mathrm{w}$ ramach działalności artystycznej lub naukowej. Uchylony przepis art. 55a ust. 3 ustawy o IPN obowiązywał w dniach do 1 marca do 17 lipca 2018 r. W tym czasie ustawa z 18 grudnia 1998 r. o Instytucie Pamięci Narodowej - Komisji Ścigania Zbrodni przeciwko Narodowi Polskiemu nie definiowała bliżej pojęć „działalności artystycznej” oraz „działalności naukowej”. Oznacza to, że w zakresie identyfikacji desygnatów pojęć „działalności artystycznej” oraz „działalności naukowej” dla potrzeb wykładni art. 55a ust. 3 ustawy o IPN ustawodawca zdecydował się pozostawić swobodę organom stosującym prawo. Pragmatyka postępowania w takiej sytuacji wskazuje, że podmiot stosujący prawo doprowadzi do zdekodowania zakresu rozpatrywanego pojęcia przy wykorzystaniu znanych nauce prawa metod wykładni tekstu prawnego ${ }^{5}$. Przy rekonstrukcji własnej zakresu tych pojęć dla potrzeb wykładni art. 55a ust 3 ustawy o IPN w grę powinno wejść m.in. poszukiwanie sposobów ujęcia tych pojęć lub ich odpowiedników ${ }^{6}$ (definicyjnego lub tylko kontekstowego) w innych aktach normatywnych składających się na obowiązujący porządek prawny. W procesie wykładni organ stosujący prawo może poszukiwać wsparcia także w relewantnych orzeczeniach judykatury oraz poglądach doktryny ${ }^{7}$.

Zważywszy na fakt, że ustawodawca zdecydował się uchylić przepis art. 55a ust. 3 ustawy o IPN, próba rekonstrukcji tych pojęć dla potrzeb niniejszej opinii traci merytoryczną zasadność.

\section{Podsumowanie}

1. Przepisy art. 55a ust. 1-3 ustawy z 18 grudnia 1998 r. o Instytucie Pamięci Narodowej - Komisji Ścigania Zbrodni przeciwko Narodowi Polskiemu, będące punktem odniesienia dla pytań sformułowanych we wstępie, przestały obo-

5 Zob. szerzej na ten temat np. L. Morawski, Zasady wykładni prawa, Toruń 2006.

6 Dla przykładu w art. 2 pkt 3 ustawy z 30 kwietnia 2010 r. o zasadach finansowania nauki (t.j. Dz.U. 2018, poz. 87, ze zm.) zdefiniowany został termin „badania naukowe”.

7 Zob. m.in.: M. Budyn-Kulik, M. Kulik, Wolność działalności artystycznej jako okoliczność wyłączająca odpowiedzialność karna [w:] Prawnokarne aspekty wolności: materiały z konferencji, Arłamów16-18 maja 2005 r., Warszawa 2006, s. 233-250; T. Gardocka, Czy w polskim prawie karnym potrzebny jest kontratyp sztuki? „Palestra” 2015, nr 1-2, s. 28 i n.; S. Jarosz-Żukowska, Ł. Żukowski, Wolność badań naukowych i nauczania [w:] Realizacja i ochrona konstytucyjnych wolności i praw jednostki w polskim porządku prawnym, red. M. Jabłoński, Wrocław 2014, s. 718 i n.; C. Starck, Wolność badań naukowych i jej granice, „Przegląd Sejmowy” 2007, nr 3, s. 45 i n. 
wiązywać z dniem 17 lipca 2018 r. Zasadniczym skutkiem prawnym decyzji ustawodawcy o uchyleniu art. 55a ust. 1 i 2 ustawy o IPN jest dekryminalizacja zachowań objętych ustawowym opisem typu czynu zabronionego określonego w tych przepisach w jego umyślnej i nieumyślnej odmianie. Oznacza to, że od dnia 17 lipca 2018 r. zachowanie realizujące znamiona opisane w uchylanych przepisach art. 55a ust. 1 albo art. 55a ust. 2 ustawy o IPN pozostaje na gruncie prawa karnego legalne i nie podlega ściganiu.

2. Walor legalności zachowań, których modelowy odpowiednik zapisany został w dyspozycjach uchylonych przepisów art. 55a ust. 1 i 2 ustawy o IPN, ogranicza się do zakresu normowania prawa karnego. Fakt dekryminalizacji nie przekłada się natomiast na ewentualną prawną ocenę tych zachowań dokonywaną przez organy państwa na gruncie innych gałęzi prawa, w tym w szczególności prawa cywilnego.

3. Sprawca dopuszczający się kłamliwego (wbrew faktom) przypisania narodowi polskiemu lub państwu polskiemu odpowiedzialności lub współodpowiedzialności za popełnienie zbrodni, w tym zbrodni rodzajowo wskazanych w uchylonym art. 55a ust. 1 ustawy o IPN, których dopuścił się kto inny, nadal powinien liczyć się z możliwością poniesienia odpowiedzialności deliktowej przed polskimi sądami z tytułu naruszenia dobrego imienia Rzeczypospolitej Polskiej lub narodu polskiego w trybie art. 53o ustawy o IPN. Przypisanie tej odpowiedzialności dokonane na gruncie prawa cywilnego może prowadzić do zasądzenia obowiązku wypłaty odszkodowania lub zadośćuczynienia na rzecz Skarbu Państwa.

4. Dekryminalizacja w odniesieniu do przestępstw $\mathrm{z}$ art. 55a ust. 1 i 2 ustawy o IPN, która zaistniała z dniem 17 lipca 2018 r., wpłynie nie tylko na ocenę zachowań przyszłych. Zgodnie z regułą intertemporalną stosowania ustawy względniejszej wobec sprawcy (art. $4 \$ 1$ Kodeksu karnego), skutkiem dekryminalizacyjnym zostaną objęte także czyny popełnione w okresie obowiązywania przepisów art. 55a ust. 1 i 2 ustawy o IPN, tj. od 1 marca do 16 lipca 2018 r., a będące przedmiotem postępowań, w których orzekanie nastąpi począwszy od dnia 17 lipca $2018 \mathrm{r}$.

5. Osoba, wobec której organy wymiaru sprawiedliwości zdążyłyby przeprowadzić $\mathrm{w}$ całości postępowanie karne o przestępstwo $\mathrm{z}$ art. 55a ust. 1 albo ust. 2 ustawy o IPN, zakończone prawomocnym skazaniem przed dniem 17 lipca 2018 r., zgodnie z dyrektywą zawartą w art. $4 \$ 4$ Kodeksu karnego, skorzysta z zatarcia skazania z mocy prawa. Jeśli w dniu 17 lipca 2018 r. (tj. dniu wejścia w życie nowej ustawy) toczyłoby się postępowanie wykonawcze dotyczące takiego wyroku (wykonywana byłaby orzeczona kara pozbawienia wolności, kara ograniczenia wolności, ewentualnie trwałby okres próby w związku z warunkowym umorzeniem postępowania albo warunkowym zawieszeniem wykonania orzeczonej kary pozbawienia wolności), przedmiotowe postępowanie należałoby umorzyć z powołaniem na art. $15 \$ 1$ Kodeksu karnego wykonawczego. 


\section{Bibliografia}

Budyn-Kulik M., Kulik M., Wolność działalności artystycznej jako okoliczność wyłączajaca odpowiedzialność karna [w:] Prawnokarne aspekty wolności. Materiały z konferencji, Arłamów, 16-18 maja 2005 r., Warszawa 2006.

Gardocka T., Czy w polskim prawie karnym potrzebny jest kontratyp sztuki?, „Palestra” 2015, nr 1-2.

Inny słownik języka polskiego PWN. A...Ó, red. M. Bańko, Warszawa 2000.

Jarosz-Żukowska S., Żukowski Ł., Wolność badań naukowych i nauczania [w:] Realizacja i ochrona konstytucyjnych wolności i praw jednostki w polskim porządku prawnym, red. M. Jabłoński, Wrocław 2014.

Kozłowska-Kalisz P., Komentarz aktualizowany do art. 28 [w:] Kodeks karny. Komentarz aktualizowany, M. Budyn-Kulik, P. Kozłowska-Kalisz, M. Kulik, M. Mozgawa, 2018, LEX nr 560561.

Lachowski J., Komentarz do art. 28 [w:] Kodeks karny. Komentarz, red. V. Konarska-Wrzosek, 2016, LEX nr 513081.

Lachowski J., Komentarz do art. 4 [w:] Kodeks karny. Komentarz, red. V. Konarska-Wrzosek, 2016, LEX nr 513055.

Morawski L., Zasady wykładni prawa, Toruń 2006.

Starck C., Wolność badań naukowych i jej granice, „Przegląd Sejmowy” 2007, nr 3.

Uniwersalny słownik języka polskiego, t. I, A-G, red. S. Dubisz, Warszawa 2003. 